\title{
Selection strategies in a segregating passion fruit population aided by classic and molecular techniques
}

\author{
Sandra da Costa Preisigke ${ }^{1^{*}}$ (D), Alexandre Pio Viana² ${ }^{\text {DD }}$, Eileen Azevedo Santos ${ }^{2}$ D, \\ Paulo Ricardo dos Santos ${ }^{3}$ (D), Valquíria Oliveira dos Santos² (D), Moisés Ambrósio² (D), \\ Flávia Alves da Silva² (D), Fernando Henrique de Barros Walter ${ }^{2}$ iD \\ 1.Universidade do Estado de Mato Grosso - Laboratório de Melhoramento Genético Vegetal - Cáceres (MT), Brazil. \\ 2.Universidade Estadual do Norte Fluminense Darcy Ribeiro - Laboratório de Melhoramento Genético Vegetal - Campos \\ dos Goytacazes (RJ), Brazil. \\ 3.Universidade Federal do Cariri - Departamento de Agronomia - Crato (CE), Brazil.
}

\begin{abstract}
Combining the use of agronomic, disease-resistance, and molecular information can greatly contribute to genetic progress in breeding programs. This study was developed to estimate the genetic distance between genotypes derived from backcrosses and their parents using morphoagronomic and molecular information and information pertaining to resistance to the Cowpea aphid-borne mosaic virus (CABMV), and indicate genotypes with potential for generation advancement. The studied population consisted of 91 genotypes from the first backcross, one interspecific hybrid, and the species Passiflora setacea and $P$. edulis. For morphoagronomic characterization, the traits number of fruits, total fruit weight, average fruit weight, and area under the disease progress curve (AUDPC, related to resistance to CABMV) were evaluated. Fourteen microsatellite primers were used to estimate genetic diversity among the genotypes, estimate diversity parameters and quantify the proportion of parental genome in the evaluated genotypes. The use of morphoagronomic and molecular information revealed the existence of genetic variability among the genotypes. The mean number of alleles is close to that expected for the population. Observed heterozygosity (0.42) was higher than the expected heterozygosity (0.30), indicating an elevated number of heterozygous individuals in the population. Due to their good agronomic performance, resistance to the virus, and genotypic and phenotypic distinction, genotypes 484 and 312 are recommended to compose the future stages of the passion fruit breeding program aimed at resistance to CABMV.
\end{abstract}

Key words: Passiflora, CABMV, backcross, parental proportion.
Received: Jul. 29, 2019

Accepted: Dec. 03, 2019

Section Editor:

Bruce Topp

${ }^{*}$ Correspondence author: sandrapreisigke@hotmail.com

\section{INTRODUCTION}

Passion fruit (Passiflora edulis Sims), a member of the genus Passiflora, the largest and most important of the family Passifloraceae, originated in the Tropical and Subtropical Americas (Vanderplank 2000).

The sour passion fruit is the main species cultivated in Brazil, due to its quality, vigor, and juice yield. The portion of fresh fruit in Brazil's total passion fruit exports is restricted to 1.5\%, because the domestic market absorbs almost all production. Concentrated juices represent the largest share of exports, achieve the best quotes and foreign exchange gains, and are most marketed in the Netherlands, the United States, Puerto Rico, Japan and Germany, which import 76\% of concentrated juice produced in Brazil (Meletti et al. 2011). 
The annual production of sour passion fruit in Brazil is approximately 602,651 t, with an estimated production worth around $\mathrm{R} \$ 244,134.60$. The average yield of this species in Brazilian orchards reached 14.6 t.ha ${ }^{-1}$ in 2018, and its potential production reaches more than $40 \mathrm{t} \cdot \mathrm{ha}^{-1}$ (IBGE 2019).

Because it is the most widely grown species, $P$. edulis is affected by various diseases, of which the fruit woodiness (hardening) virus caused by Cowpea aphid-borne mosaic virus (CABMV) is one of the most economically important. The CABMV belongs to the genus Potyvirus in the family Potyviridae. The virus can be transmitted by various aphid species (Aphis fabae Scopoli, Aphis nerii Boyer from Fonscolombe, Aphis gossypii Glover, Myzus nicotianae Blackman and Myzus persicae Sulzer) in a nonpersistent manner. They can also be easily transmitted via buffered leaf extract and grafting (Zerbini et al. 2005; Di Piero et al. 2006).

Infected plants exhibit mosaic, blistering and distortion on the leaves, reduction of plant size, woodiness, deformation and pulp reduction of the fruits (Oliveira et al. 2013a).This disease cause a major economic impact in the growing of passion fruit, as it reduces the yield and productive period of the crop and the commercial value of the fruits (Cerqueira-Silva et al. 2015).

There is no genetic variability for resistance to CABMV within the commercial species $P$. edulis. Thus, breeding programs resort to wild species to elevate the resistance level of commercial cultivars through interspecific hybridizations (Fonseca et al. 2009; Freitas et al. 2015; Santos et al. 2015 b).

The passion fruit breeding program for genetic resistance to CABMV from the Universidade Estadual do Norte Fluminense Darcy Ribeiro (UENF) has showing promising results. This program started with the work of Santos et al. (2014), by obtaining interspecific hybrids between P. setacea (resistant to CABMV) and P. edulis (commercial species susceptible to CABMV). After obtaining them, the hybrids were evaluated for resistance to CABMV (Santos et al., 2015 b) and agronomic traits (Santos et al. 2015 a; Freitas et al. 2016). Continuing the program, Santos et al. (2019 a) performed QTL mapping for virus resistance in a $\mathrm{BC}_{1}$ segregating population and found evidence of at least seven small effect loci involved in inheritance control, corroborating the study by Freitas et al. (2015). Carvalho et al. (2019) reported in a proteasome study with passion fruit $\times$ CABMV interaction that the disease manifests by a failure in the signaling system of susceptible species, which even activating some response routes, these are not efficient in controlling of the disease. The hybrids $\left(\mathrm{BC}_{1}\right.$ ) obtained in this study were assessed for their morphology (Santos et al. $2019 \mathrm{~b}$ ) and are being evaluated for CABMV resistance and agronomic traits, but do not have the agronomic traits required by the consumer market. Therefore, several generations of backcrossing are necessary to recompose the genome of the commercial species maintaining a satisfactory resistance level.

For significant gains in genetic progress with genotype selection in the advancement of generations in a breeding program, it is necessary to know the genetic variability in the study population. Characterization may be of morphoagronomic, reproductive, biochemical, cytogenetic, or molecular nature. In this regard, morphoagronomic and molecular analyses are amongst the most commonly used tools to estimate genetic diversity (Marić et al. 2004; Ramos et al. 2012).

For the analysis of genetic diversity via morphoagronomic traits, multivariate methods are employed, in which two traits can be simultaneously evaluated. There are several methods available to estimate genetic diversity. The choice of the method depends on the type of variable to be analyzed. By using these data, a large amount of phenotypic information can be generated, making it possible to divide genotypes into groups and better plan crosses (Spooner et al. 2005).

Another widely used approach for the evaluation of genetic diversity are genetic molecular markers. Some complications such as the environmental effect, the time necessary for evaluations, among others, can be avoided by using the direct analysis of genotype via DNA molecular markers (Marić et al. 2004; Ramos et al. 2012). At present, the generation of selectively bred varieties tends to incorporate molecular-genetic methodologies, which contributes to increasing the accuracy of the selection process. The efficiency of backcrossing can be significantly increased through the association with molecular markers, which is useful for estimating the genomic proportion of individuals and accelerating the recovery of the recurrent parent genome (Ramos et al. 2012). However, most studies using the microsatellite markers in passion fruit are related to the development of these markers (Pádua et al. 2005; Cazé et al. 2012; Penha et al. 2013; Oliveira et al. 2013 b; Santos et al. 2014, Cerqueira-Silva et al. 2014 b), insertion of marks in previously constructed genetic maps (Oliveira et al. 2008; Pereira et al. 2013) and genetic diversity (Oliveira et al. 2013 b; Paiva et al. 2014; Cerqueira-Siva et al. 2014 a). 
In breeding programs, it is important to make use of these two categories of information (molecular and morphoagronomic), given their contribution to the understanding of the genetic relationship existing in the studied germplasm (Ramos et al. 2012). On this basis, the objectives of this study were: i) to estimate the genetic distance between genotypes derived from a backcross and their parents, using morphoagronomic, resistance, and molecular information; ii) to undertake a genetic characterization by estimating genotypic indexes for the quantification and structuring of genetic variability; iii) estimate the genomic proportion of the recurrent parent in the population evaluated; iv) to conduct a joint analysis based on morphoagronomic and molecular information; and v) to select superior genotypes for generation advancement in the passion fruit breeding program aimed at resistance to CABMV.

\section{MATERIAL AND METHODS}

\section{Germplasm}

One full-sib family (160 BC 1 genotypes), an interspecific hybrid (resistance genes donor parent), and the species P. setacea (resistant) and P. edulis (recurrent and susceptible parent) were conducted in the field (Table 1). The interspecific hybrid was obtained from the cross between the species P. edulis $\times$ P. setacea in the passion fruit breeding program aimed at genetic resistance to CABMV developed by Santos et al. (2015 a, b).

The backcrosses were made in the experimental area where the hybrids obtained by Santos et al. $(2015 \mathrm{a}, \mathrm{b})$ were conducted. Pollinations were carried out before flower opening, starting at $10 \mathrm{~h}$. By that time, the P. edulis anthers were already open. P. edulis genotypes were used as male parents and the interspecific hybrid was used as the female parent. Flower buds of the hybrids were emasculated and pollinated with pollen from the P. edulis genotypes and subsequently protected. These crosses originated five $\mathrm{BC}_{1}$ full-sib families.

\section{Experimental procedures}

The interspecific hybrid was propagated asexually via herbaceous cuttings rooted into 72-cell trays containing organic substrate and maintained in a fog chamber until complete rooting. Subsequently, rooted cuttings were transplanted to black polyethylene plastic bags and kept in a greenhouse. They were propagated by seeding the donor parent $P$. setacea (UENF germplasm bank) and the recurrent parent $P$. edulis (UENF cultivar Rio Dourado).

Seeds were washed in running water and kept for $15 \mathrm{~min}$ in a $50 \%$ sodium hypochlorite: $50 \%$ water solution. After washing, seeds were sown in a 128-cell Styrofoam tray containing organic substrate and maintained in a fog chamber until the seedling stage. Subsequently, seedlings were transplanted to black polyethylene bags with $1 \mathrm{~L}$ capacity containing vegetable soil, substrate, and sand (1:1:1 ratio) and transferred to a greenhouse. After 95 days, the seedlings were transplanted to the field in the experimental area. The experiment was set up as a randomized block design with four replicates unbalanced for plants within families.

Table 1. Origin and identification of the study populations composed by the parents: $P$. edulis, $P$. setacea, interspecific hybrid (HI) and a population of the first generation of backcrossing $\left(\mathrm{BC}_{1}\right)$.

\begin{tabular}{|c|c|c|c|}
\hline Description & Origin & Total number of genotypes & Number of selected genotypes \\
\hline $\mathrm{FIC}^{*}$ & HI5-14 × P. edulis & 160 & 91 \\
\hline Parent HI5-14** & Ps $367 \times$ Pe 139 (40) & 12 & 1 \\
\hline Parent $P$. edulis & ***UENF ‘Rio Dourado' & 12 & 1 \\
\hline Parent P. setacea & BAG from UENF & 12 & 1 \\
\hline Total & & & 94 \\
\hline
\end{tabular}

${ }^{*}$ Full-sib family - first generation backcrossing. ${ }^{* *}$ Selected interspecific hybrids (Santos et al. 2015). Pe = P. edulis; Ps $=$ P. setacea. ${ }^{* * *}$ Cultivar developed by Breeding Program Passionflower (PMGMA-UENF). 
Plants were conducted in the field using vertical stakes with $2.5 \mathrm{~m}$ high fence posts spaced $4 \mathrm{~m}$ apart, with 12 -gauge wire at $1.80 \mathrm{~m}$ from the soil. The distance between planting rows and between furrows was 3.5 and $2 \mathrm{~m}$, respectively. Upon planting, $10 \mathrm{~L}$ cattle manure, $200 \mathrm{~g}$ limestone, $400 \mathrm{~g}$ single superphosphate, and $250 \mathrm{~g}$ potassium chloride were applied in the furrows. The drip irrigation system was adopted. Pests and diseases were controlled with phytosanitary products recommended for the crop by the Brazilian Ministry of Agriculture, Livestock, and Food Supply. During the experiment period in the field, temperatures ranged from 17.6 to $34.7^{\circ} \mathrm{C}$, and average rainfall was $75.01 \mathrm{~mm}$, ranging from 17 to $205.8 \mathrm{~mm}$.

\section{Morphoagronomic and resistance characterization}

Of the 94 genotypes identified in Table 1, only 77 produced fruits, including the parents. Thus, they were evaluated for the following production and CABMV-resistance traits:

- Area under the disease progress curve (AUDPC): The populations were conducted in an area with a history of the disease, where they were evaluated under natural occurrence of CABMV. After the appearance of the first viral symptoms, plants were fortnightly evaluated for 14 months. Symptoms were visually assessed on young leaves - from the third youngest leaf on new branches / and whole plant - distribution of viral symptoms throughout the area occupied by the plant. A scale of scores ranging from 1 (no symptoms) to 4 (severe symptoms, with modifications) proposed by Novaes and Rezende (1999) and modified by Oliveira et al. (2013 a) (Fig. 1). The AUDPC was estimated for young leaves and total plant area using a scale of scores. After the estimates, an average was obtained from the AUDPCs (AAUDPC).

- Number of fruits per plant (NF): Fruits were harvested twice weekly for nine months, and at the end of the evaluation period, the total number of fruits per genotype was counted.

- Total fruit weight (TFW): The fruits were weighed on a semianalytical digital scale and their weight was expressed in grams (all fruits were ripe and collected throughout the evaluation period).

- Average fruit weight (AFW): Determined as the arithmetic mean of one sampling of at least one and at most 15 fruits from each genotype. The fruits were weighed individually on a semianalytical digital scale and their weight was expressed in grams.

(a)

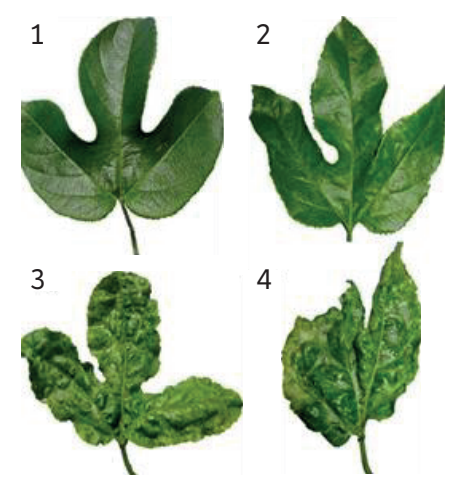

(b)

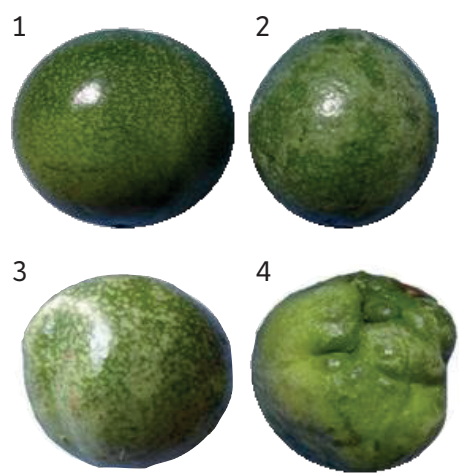

(c)

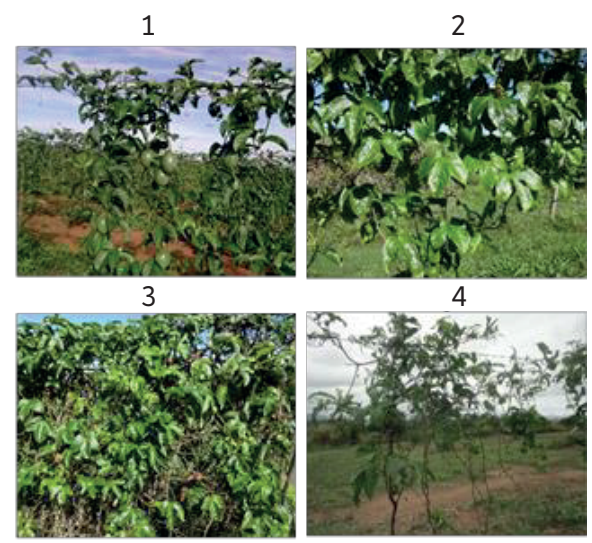

Figure 1. Symptoms of passion fruit virus disease: (a) Young leaf scale ranging from 1 for plants without symptoms to 4 more severe symptoms; (b) fruit scale ranging from 1 fruit without symptoms to 4 more severe symptoms; (c) total airway score scale occupied by the plant ranging from 1 (plants without symptoms) to 4 (more severe symptoms). 
The distance matrix was obtained using information of agronomic and resistance traits, based on Euclidian distance (Eq. 1).

$$
d_{i i}=\sqrt{\frac{1}{n} \sum_{j}\left(x_{i j}-x_{i^{\prime} j}\right)^{2}}
$$

With the distance matrix, the dendrogram was constructed by the unweighted pair group method with arithmetic mean (UPGMA) method. All analyses were carried out using R software (R Core Team, 2019).

\section{Genotyping}

For DNA extraction, 91 genotypes from a full-sib family; one genotype of the interspecific hybrid (resistance-donor genotype); one genotype of parent $P$. edulis; and one genotype of ancestor $P$. setacea were selected (Table 1). These 91 genotypes from the first generation of backcross within the family were selected based on the diversity of virus-infection symptoms exhibited by the genotypes on the collection of genetic material.

Information obtained from the genotyping of the 94 individuals (Table 1) was used to perform an analysis at molecular level only, with a view to obtaining the genetic structure of the population, estimating the genetic distance between individuals, and estimating diversity parameters. The 77 individuals that bore fruit were also genotyped for a joint analysis including the resistance, molecular, and production variables.

\section{Genomic DNA extraction and quantification}

Total genomic DNA extraction was performed on young leaves collected individually from each genotype, using the standard CTAB method with modifications (Doyle and Doyle, 1990). Subsequently, the DNA was extracted by analysis on $1 \%$ agarose gel with $1 \mathrm{X}$ TAE buffer (Tris, sodium acetate, EDTA, pH 8.0), using a 100-pb lambda $(\lambda)$ marker $\left(100\right.$ ng. $\left.\mu \mathrm{L}^{-1}\right)$ (Invitrogen, USA) by comparison of bands. For this procedure, samples were stained using a Gel Red:Blue Juice mixture (1:1), and the image was captured by the Mini Bis Pro imaging system (Bio-Imaging Systems). Later, DNA samples were diluted to a working concentration of $10 \mathrm{ng} \cdot \mu \mathrm{L}^{-1}$.

\section{Primer screening}

The DNA of parental genotypes was used initially for a screening with 63 microsatellite primers developed for $P$. edulis (Oliveira et al. 2008; Cerqueira-Silva et al. 2014 b), aiming to identify SSR loci able to distinguish the parents. After screening, 14 polymorphic primers were selected for the amplification reactions (Table 2).

\section{Polymerase-chain reaction (PCR)}

Polymerase-chain reactions were carried out in 96-well thermocyclers (Applied Biosystems/Veriti) using a 35-cycle program in which the following temperatures and times were observed: $94^{\circ} \mathrm{C}$ for $4 \mathrm{~min}$ (initial denaturation); $94{ }^{\circ} \mathrm{C}$ for $2 \mathrm{~min}$ (cyclic denaturation); specific temperature of each primer, in ${ }^{\circ} \mathrm{C}$, for $1 \mathrm{~min}$ (annealing); $72{ }^{\circ} \mathrm{C}$ for 2 min (cyclic extension); $72{ }^{\circ} \mathrm{C}$ for $10 \mathrm{~min}$ (final extension); and $4^{\circ} \mathrm{C}$ forever. The final volume was $13 \mu \mathrm{L}$ of each sample, consisting of $2 \mu \mathrm{L}$ DNA $\left(5 \mathrm{ng} \cdot \mu \mathrm{L}^{-1}\right), 1.50 \mu \mathrm{L} 10 \mathrm{X}$ buffer $\left(\mathrm{NH}_{4} \mathrm{SO}_{4}\right), 1.5 \mu \mathrm{L} \mathrm{MgCl}_{2}\left(25 \mathrm{mmol} \cdot \mathrm{L}^{-1}\right), 1.5 \mu \mathrm{L}$ dNTPs $\left(2 \mathrm{mmol} \cdot \mathrm{L}^{-1}\right), 1 \mu \mathrm{L}$ primer $(\mathrm{R}+\mathrm{F})$ $\left(5 \mu \mathrm{mol} \cdot \mathrm{L}^{-1}\right)$, and $0.12 \mu \mathrm{L}$ Taq-DNA polymerase $\left(5 \mathrm{U} \cdot \mu \mathrm{L}^{-1}\right)$ (Invitrogen, Carlsbad, California, USA).

The PCR products were diluted at a ratio of $4 \mu \mathrm{L}$ of sample for $20 \mu \mathrm{L}$ of Buffer E from the DNF 900 and dis kit and subjected to a capillary electrophoresis system (Fragment Analyzer - AATI) in which amplified fragments of 35 to 500 pb were separated at a resolution of approximately $2 \mathrm{bp}$. Each run lasted $2 \mathrm{~h} 20 \mathrm{~min}$, at a voltage of $8 \mathrm{~kW}$. 
Table 2. Sequence the 14 microsatellite primers developed for Passiflora, used in the genetic diversity analysis of passion fruit segregating populations.

\begin{tabular}{|c|c|c|}
\hline Primer & Sequence (5' $\left.3^{\prime}\right)$ & $\mathrm{T}\left({ }^{\circ} \mathrm{C}\right)$ \\
\hline PE 96 & $\begin{array}{l}\text { F: GGTTTTGCTTGATTACTTTTC } \\
\text { R: GGATCTTCCCAAATGACTC }\end{array}$ & 56 \\
\hline Pad-2 & $\begin{array}{c}\text { F: CACATTTGCCGTCACTGG } \\
\text { R: CGGCATACGATAAATCTCCTG }\end{array}$ & 58 \\
\hline Ps-16 & $\begin{array}{l}\text { F: GAGAAAGCGAGTCAGCGAGA } \\
\text { R: GACTCCAATATCGGCACTTCA }\end{array}$ & 58 \\
\hline Ps-9 & $\begin{array}{l}\text { F: GGGCCGTTGTCAAAGTAGT } \\
\text { R: GAGGTTAAGGCAAGCACTG }\end{array}$ & 60 \\
\hline Ps-2 & $\begin{array}{l}\text { F: TAGCTTAACACAATGCAACAGA } \\
\text { R: CAACGGAGAACGATGTCAG }\end{array}$ & 56 \\
\hline PE 43 & $\begin{array}{l}\text { F: GGAATCACTCTTGCGCTTCT } \\
\text { R: TCTGTCTTATGCCACTGTTGG }\end{array}$ & 60 \\
\hline PE 32 & $\begin{array}{l}\text { F: GGCCAACCATTCAACCAATA } \\
\text { R: CAAGCACATGAATCAAAATCG }\end{array}$ & 60 \\
\hline PE 21 & $\begin{array}{l}\text { F: CCCGGAAGATTGGTCGTA } \\
\text { R: ATCCAATGGCAGGAAGGTC }\end{array}$ & 60 \\
\hline PE 34 & $\begin{array}{l}\text { F: ACTTGCGTGTGATTGTTGT } \\
\text { R: GAAGATTGCCTACTCGTCC }\end{array}$ & 58 \\
\hline PE 40 & $\begin{array}{l}\text { F: ACAACAAAGACTGCGGGAAC } \\
\text { R: CTTCTTTTGGGTTGCTCTCTG }\end{array}$ & 58 \\
\hline PE 25 & $\begin{array}{l}\text { F: TAGAGAAAAGCACACACACA } \\
\text { R: CGAGGTCGAGTTTACAGAAA }\end{array}$ & 62 \\
\hline PE 74 & $\begin{array}{l}\text { F: CCCTCTTATCAATAGCGTTGG } \\
\text { R: GCACGAGCACGAGTATTTATT }\end{array}$ & 64 \\
\hline PE 7 & $\begin{array}{l}\text { F: TGCTCATTGATGGTGCTTG } \\
\text { R: TCGTCTCTTCTCCTCCTTCA }\end{array}$ & 58 \\
\hline PE 76 & $\begin{array}{l}\text { F: ACTGCTTCTTGATTCCGATAA } \\
\text { R: CTACTTACCCGCTGACACAC }\end{array}$ & 58 \\
\hline
\end{tabular}

\section{Statistical analysis of molecular variables}

The data obtained from the amplification of the 14 SSR primers were converted into a numeric code for each allele per locus. This numerical matrix was developed by assigning values from 1 to the maximum number of alleles in the locus, as follows: for a locus with three alleles, the homozygous forms are represented by the Figs. 11, 22, and 33 (A1A1, A2A2, and A3A3), whereas the heterozygosity forms are represented by 12, 13, and 23 (A1A2, A1A3, and A2A3). Based on this numerical matrix, Rogers genetic distance was calculated for both the 77 and the 94 genotypes of the segregating population. The cluster analysis of the individuals via dendrogram was undertaken by the UPGMA method using R software (R Core Team, 2019). 
The genetic diversity parameters number of alleles per polymorphic locus (NA), observed heterozygosity (Ho), expected heterozygosity (He), information index (I), and fixation index (f) were estimated considering the 94 individuals.

\section{Analysis of proportion of recurrent parent genome}

The proportion of recurrent parent genome transferred to the $94 \mathrm{BC}_{1}$ individuals was analyzed using the method proposed by Benchimol et al. (2005) with the formula $\mathrm{PR}=\mathrm{B}+0.5 \mathrm{H} /(\mathrm{B}+\mathrm{H})$, where $\mathrm{B}$ is the number of plants with the recurrent allele and $\mathrm{H}$ is the number of plants with the heterozygote genotype. The data obtained were used to determine the proportion of recurrent parent genome in each individual from the population.

\section{Joint analysis of morphoagronomic and molecular variables}

The distance matrices relating the agronomic and resistance variables and the matrices obtained based on the microsatellite markers were compared for the 77 genotypes using the Dendextend package in the R software (R Core Team, 2019).

\section{RESULTS AND DISCUSSION}

\section{Selection via agronomic and resistance traits}

The agronomic and resistance traits led to the formation of six distinct groups with a cut-off point of approximately 0.2 (Fig. 2). Although few variables were used, genetic diversity and group formation were observed. Analogously to this study, Silva et al. (2013) used only one trait of resistance to the fungus Fusarium oxysporum f. sp. passiflorae to estimate genetic diversity in passion fruit and Assmann et al. (2010) used three traits of resistance to the leaf rust to distinguish peach genotypes. In the present study, in addition to the use of one variable of resistance to CABMV, another three production-related traits were used for the distinction of the genotypes, providing greater robustness to the analysis.

The most distant genotypes regarding the evaluated traits were $P$. edulis (recurrent parent) and $\mathrm{BC}_{1} 176(0.96)$, as the latter produced only two fruits with an average weight of $27.88 \mathrm{~g}$. For the disease resistance trait, $\mathrm{BC}_{1} 176 \mathrm{obtained}$ an AAUDPC of 502.50 and was thus considered not resistant. This value was much lower than the 1241.25 estimated for P. edulis.

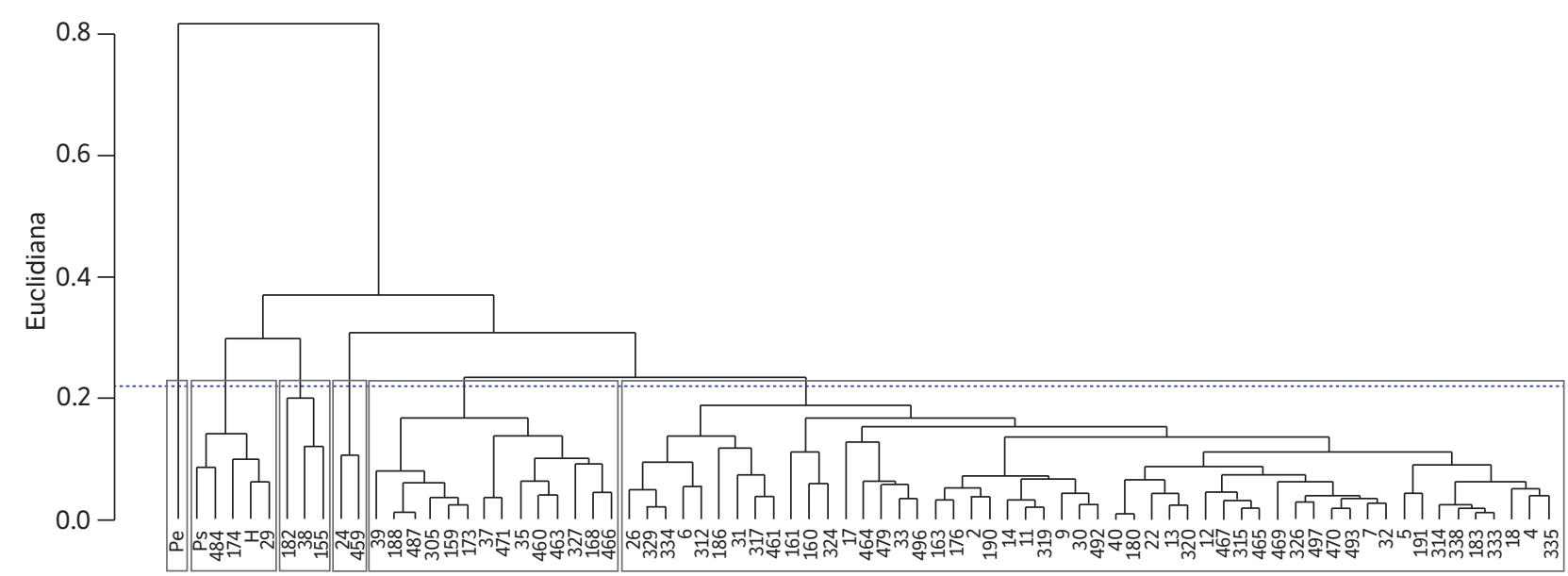

Figure 2. Genetic dissimilarity dendrogram among 77 genotypes of a passion fruit segregating population including the parents, obtained by the UPGMA method, based on the agronomic traits and resistance to the disease. 
The genotypes $\mathrm{BC}_{1} 188$ and $\mathrm{BC}_{1} 487$ were the most similar (0.01). Both were susceptible to the virus (AAUDPC 825) and produced only two fruits, with an average weight between 39.68 and $42.01 \mathrm{~g}$. Plants with those characteristics are not suitable to compose the next stage of the breeding program aimed at resistance in passion fruit.

The genotype that showed the greatest similarity to the recurrent parent, P. edulis, was 38 (0.54). This genotype displayed good productive traits, but was susceptible to the disease. The genotype most similar to the resistant species (P. setacea) was $\mathrm{BC}_{1} 484$, which showed good agronomic performance, with a high number of fruits (86), which was close to the 96 fruits produced by the recurrent parent, although its average fruit weight was relatively low (53.86). It is a CABMVresistant genotype with a low AAUDPC (450), which was near the 401.25 obtained by the resistant species, and thus it can be recommended for the composition of the next stage of the breeding program.

Group I contained only one genotype: recurrent parent $P$. edulis, which is the productivity-standard goal of the passion fruit breeding program, but including genes of resistance to CABMV. It was isolated from the other individuals possibly due to its high production and susceptibility to CABMV.

Group II contained five genotypes: the species resistant to CABMV, the interspecific hybrid, and three genotypes from the first backcross generation. These three have average fruit weight in common, which ranged from 34.97 to $53.86 \mathrm{~g}$. These are low values when compared with the $137.01 \mathrm{~g}$ shown by the recurrent parent. Number of fruits in this group ranged from 56 to 83 , which is close to the 96 fruits produced by the recurrent parent. As regards the disease-resistance trait, there was a greater variation in the AAUDPC between the genotypes of this group (401.25 to 570). The $\mathrm{BC}_{1}$ genotypes that compose this group are indicated as parents for the first backcross generation, since they have satisfactory agronomic performance and are resistant to CABMV, except genotype 29, which had the highest AAUDPC (570).

Group III included three genotypes from the first backcross generation, all of which were susceptible to CABMV, with an AAUDPC between 750 and 1076.25. By contrast, they showed good agronomic performance, with average fruit weight ranging from 62.69 to $66.81 \mathrm{~g}$ and number of fruits varying between 45 and 69.

Group IV contained two genotypes from the first backcross generation, both susceptible to CABMV, with an AAUDPC between 926.25 and 1095. These genotypes produced few (between 2 and 5), but heavier fruits (94.24 and $101.45 \mathrm{~g}$ ).

Group V had 14 genotypes from the first backcross generation. In this group, the agronomic performance of the individuals was low, with fruit weight ranging from 25.74 to $69.84 \mathrm{~g}$ and number of fruits from 1 to 23 . In terms of resistance to CABMV, all genotypes were susceptible, with elevated AAUDPCs (825 to 1113.75).

Group VI was formed by 52 individuals; most genotypes from the first backcross generation were allocated to this group. There was a wide variation for resistance to CABMV within it, with AAUDPC values of 442.50 to 787375 between resistant and susceptible genotypes. Number of fruits and fruit weight ranged from 1 to 29 and 25.50 to $101.68 \mathrm{~g}$, respectively. Most genotypes from this group exhibited low agronomic performance and moderate resistance to CABMV.

The $\mathrm{BC}_{1}$ population evaluated in this study showed high variation in number and weight of fruits, with some genotypes closer to the recurrent parent. This information was expected, since it has a higher proportion of the P. edulis genome, compared to the population evaluated by Santos et al. (2015 a, b) that was obtained from interspecific crossing. On the other hand, Santos et al. (2015 a, b) reported asymptomatic genotypes and considered resistant by serological tests. In this study, although satisfactory levels of resistance were observed, no asymptomatic genotype was observed. This is probably due to the polygenic character of CABMV resistance, as suggested by Freitas et al. (2015) and Santos et al. (2019 a).

\section{Selection and characterization via microsatellite markers}

Regarding genetic diversity for the 77 evaluated genotypes, a total of 31 alleles were obtained considering the 14 evaluated loci. The number of alleles per locus varied from 2 to 3 , averaging 2.21. This value is close to expected, since the evaluated population derives from a bi-parental cross between diploid and heterozygous species (Table 3 ).

Silva et al. (2015) used SSR loci developed for P. edulis to characterize a population of passion fruit in the third recurrent selection cycle and observed that the number of alleles per locus varied from 2 to 6 , averaging 2.9, which is similar to the values obtained in the current trial. Paiva et al. (2014) evaluated 56 accessions of Passiflora and found three to five alleles 
Table 3. Number of alleles (NA); Information index (I); Expected heterozygosity (He); Observed heterozygosity (Ho) and fixation index (I), estimated for 94 Passiflora genotypes including $\mathrm{BC}_{1}$ and the parents.

\begin{tabular}{|c|c|c|c|c|c|}
\hline Locus & NA & I & $\mathrm{He}$ & Ho & $F$ \\
\hline PE96 & 2.00 & 0.08 & 0.03 & 0.01 & 0.66 \\
\hline Pad-2 & 2.00 & 0.66 & 0.47 & 0.74 & -0.57 \\
\hline Ps-16 & 2.00 & 0.68 & 0.49 & 0.30 & 0.37 \\
\hline Ps-9 & 2.00 & 0.03 & 0.01 & 0.01 & -0.00 \\
\hline Ps-2 & 2.00 & 0.54 & 0.35 & 0.46 & -0.30 \\
\hline PE 43 & 3.00 & 0.67 & 0.43 & 0.58 & -0.35 \\
\hline PE 32 & 2.00 & 0.03 & 0.01 & 0.01 & -0.00 \\
\hline PE 21 & 3.00 & 1.02 & 0.61 & 0.96 & -0.56 \\
\hline PE 34 & 3.00 & 0.72 & 0.50 & 0.95 & -0.89 \\
\hline PE 40 & 2.00 & 0.60 & 0.41 & 0.57 & -0.36 \\
\hline PE 25 & 2.00 & 0.67 & 0.47 & 0.76 & -0.60 \\
\hline PE 74 & 2.00 & 0.03 & 0.01 & 0.01 & -0.00 \\
\hline PE 7 & 2.00 & 0.56 & 0.38 & 0.48 & -0.28 \\
\hline PE 76 & 2.00 & 0.08 & 0.03 & 0.01 & 0.66 \\
\hline Average & 2.21 & 0.45 & 0.30 & 0.42 & -0.16 \\
\hline
\end{tabular}

per locus, which is considered low when compared with results from other studies of diversity of the genus (Oliveira et al. 2013 b; Cerqueira-Silva et al. 2014 a). Although some authors (Oliveira et al. 2013 b; Cerqueira-Silva et al. 2014 a) found an allelic variation of 18 to 20, the number of alleles per locus in the genus Passiflora is considered low; further, there are few polymorphic microsatellite markers (Cerqueira-Silva et al. 2014 a), which may suggest that these loci are concentrated in conserved regions, with a low mutation rate (Paiva et al. 2014). It is noteworthy that the above-mentioned studies refer to investigations of diversity between Passiflora species, which explains the higher number of observed loci.

The information index ranged from 0.03 to 1.02 , considering all evaluated genotypes. The average information index of 0.45 indicates the existence of moderate variability in this population, but it is sufficient for the continuity of this breeding program. This index defines that diversity will increase as the estimated values approach unity.

Expected $(\mathrm{He})$ and observed $(\mathrm{Ho})$ heterozygosity values ranged from 0.01 to 0.61 and from 0.01 to 0.96 , respectively. Observed heterozygosity was only lower than He for the loci PE 96, PS-16, and PE 76. On average, Ho (0.30) was higher than $\mathrm{He}(0.42)$, indicating an elevated number of heterozygous individuals, which was expected, since those are allogamous, heterozygous, and self-incompatible plants.

Paiva et al. (2014) evaluated genetic diversity of Passiflora species and observed an average Ho of 0.52, which is close to that observed in this study. Cerqueira-Silva et al. (2015) found the same mean value for Ho (0.42) in an evaluation of genetic diversity in P. edulis genotypes from a germplasm bank of the Brazilian Corporation of Agricultural Research. The higher Ho than He contributed to a negative fixation index with an average of - 0.16 , indicating a higher number of heterozygotes in the population.

Genetic distances between the genotypes ranged from 0 to 13.65. The largest distance was observed for genotypes 333, 335, and 463 with P. setacea (13.65). The closest genotypes were 7 and 12; 17 and 24, 40, and 183; 26 and 155, 173, and 326; 29 and 191; 31 and 459;32, 37 and 460; 35 and 469, 161 and 180; 315 and 493; 333, 335, and 463; 334 and 468; and 467 and 479 (Fig. 3). The individuals closest to the ancestor, P. setacea, were $\mathrm{BC}_{1}$ hybrids 11, 35, and 469. Those closest to the recurrent parent, P. edulis, in turn, were $\mathrm{BC}_{1} 7,12$, and 319 . None of these genotypes showed good agronomic performance, thus being susceptible to the virus. 
Considering the genetic distance value of 0.2, four larger groups were observed, including most part of the genotypes, plus three groups that contained only one genotype, indicating the existence of genetic variability between the analyzed genotypes (Fig. 3). Groups I, II, and V each had only one genotype (Fig. 3), which were considered the most divergent, namely $P$. setacea, the hybrid, and $\mathrm{BC}_{1} 168$, respectively. Fonseca et al. (2009) evaluated recurrent genome recovery in $\mathrm{BC}_{4}$ and $\mathrm{BC}_{5}$ plants $[($. edulis $\times$ P. setacea $) \times P$. edulis $]$ based on RAPD markers and, like in this study, they found isolation of $P$. setacea in relation to the other evaluated plants.

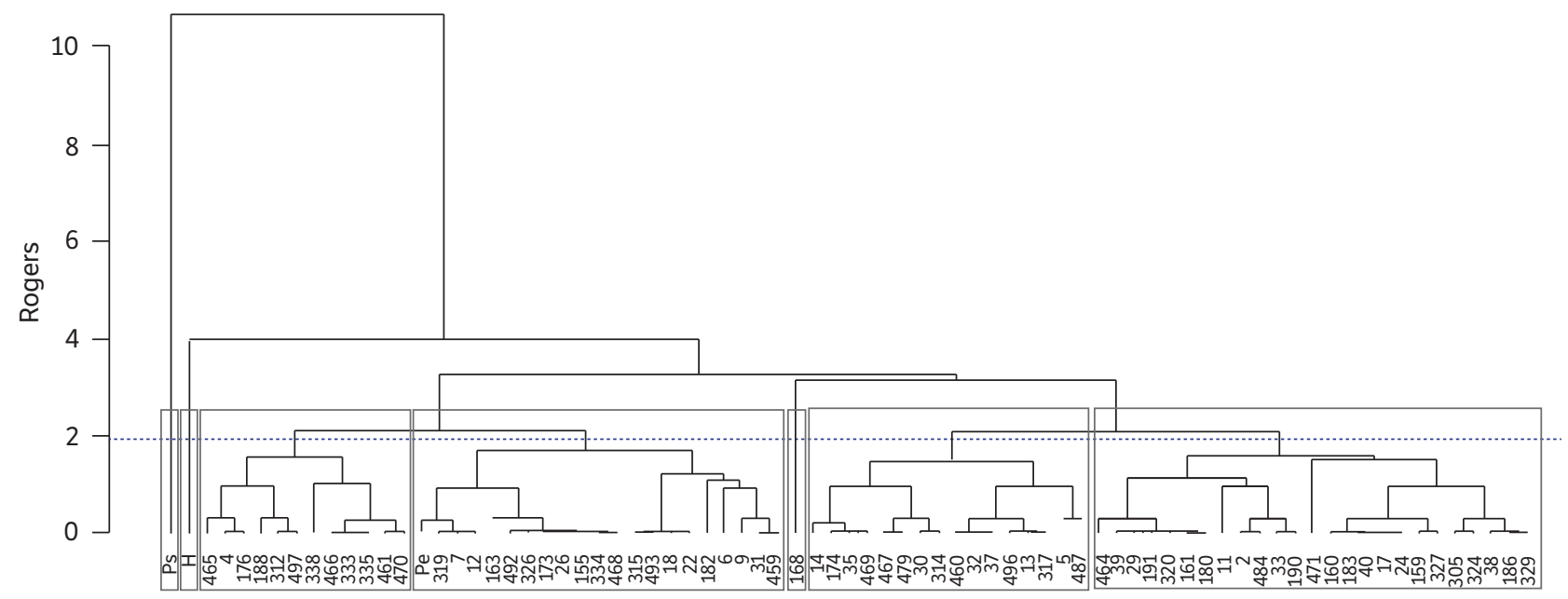

Figure 3. Genetic dissimilarity dendrogram among 77 genotypes of a passion fruit segregating population, including the parents, obtained by the UPGMA method, based on 14 microsatellite markers.

Groups IV and VII contained the highest number of genotypes, totaling 46 individuals ( 21 in group IV and 25 in group VII) corresponding to approximately $59.74 \%$ of the studied genotypes. The recurrent parent was allocated to group IV. In this group, only genotypes 155, 182, and 22 had good agronomic performance, while genotype 163 was considered resistant to the disease, but did not show satisfactory agronomic performance. A high number of $\mathrm{BC}_{1}$ genotypes were allocated to the same group as $P$. edulis, which was expected, since, in theory, an average recurrent genome recovery of $75 \%$ is expected in $\mathrm{BC}_{1}$, considering the use of the same recurrent parent. Fonseca et al. (2009) found an average genomic proportion of the recurrent parent of $84.4 \%$ in $\mathrm{BC}_{4}$ and $92.19 \%$ in $\mathrm{BC}_{5}$ plants. Groups III and VI allocated 12 and 16 genotypes, respectively. These groups were formed only by genotypes from the first backcross generation.

\section{Analysis of proportion of parent genome}

Because of the codominant nature of microsatellite markers, it is possible to estimate the percentage recovery of the recurrent parent. At each backcross generation, the mean proportion of recurrent genome recovery $(\mathrm{PR})$ in the progeny is expected to be similar to the recurrent parent at the order of $1-(1 / 2)^{t+1}$ (Allard, 1971). In the present study, the proportion of recurrent parent genome ranged from 71 to $92 \%$, averaging $83 \%$, which is above the expected, considering all evaluated genotypes (Fig. 4).

The genotypes closest to the recurrent parent were 319 (92\%), 7, and 12 (89\%) (Fig. 4). These results corroborate the dendrogram obtained by the UPGMA clustering method. Unlike the findings of this study, Fonseca et al. (2009) evaluated genome recovery in passion fruit genotypes from generations $\mathrm{BC}_{4}$ and $\mathrm{BC}_{5}$ and found mean values below the expected for these generations. Although these genotypes have a larger proportion of the recurrent parental genome, they showed low performance for the evaluated agronomic traits and moderate resistance to CABMV. This can be explained by the fact that the evaluated loci did not represent the entire genome variation; moreover, these loci are situated in random regions and are not related to express sequences of the genome. 


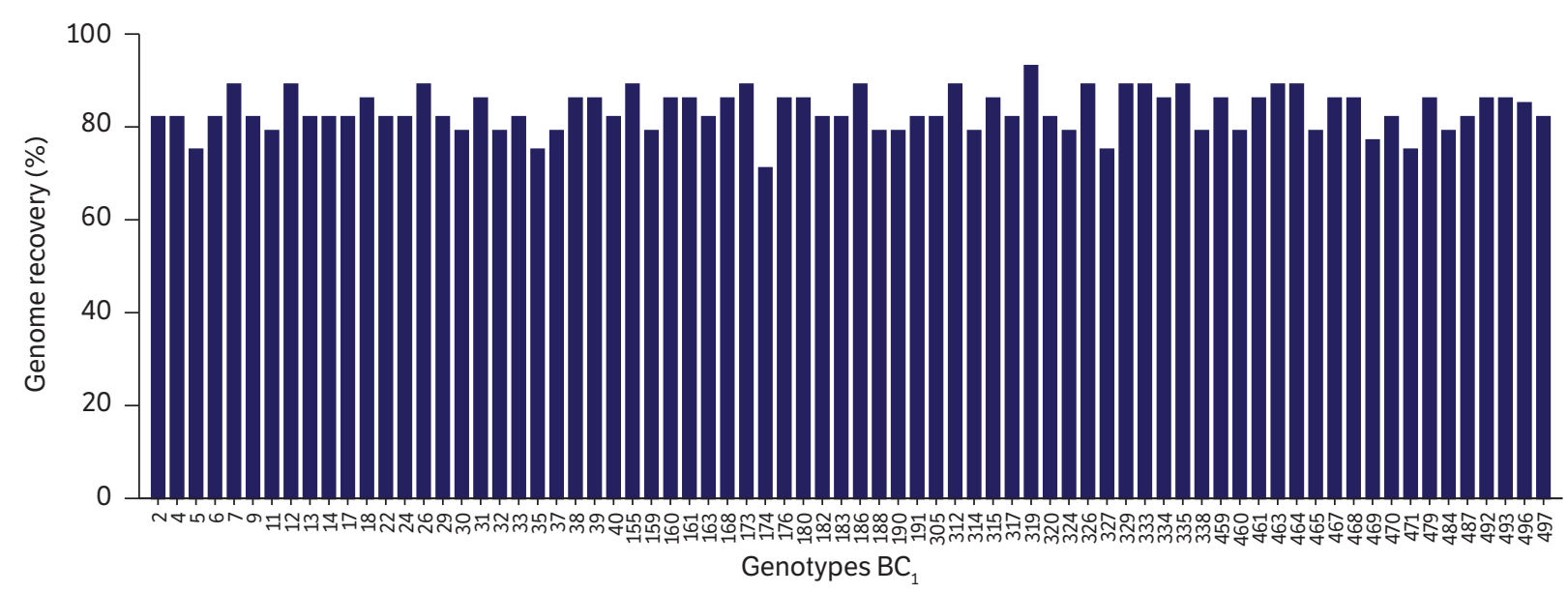

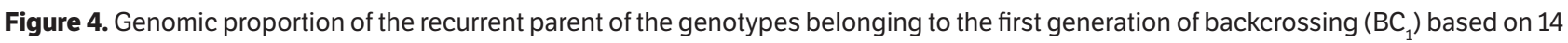
microsatellite markers.

\section{Joint analysis of morphoagronomic and molecular variables}

Based on joint analysis, seven groups were formed for molecular data and six for agronomic data. However, the arrangement of genotypes in the analysis differed (Fig. 5). The entanglement rate measures the level of entanglement between two dendrograms, which range from 1 (complete entanglement) to 0 (none). In this study, an entanglement rate
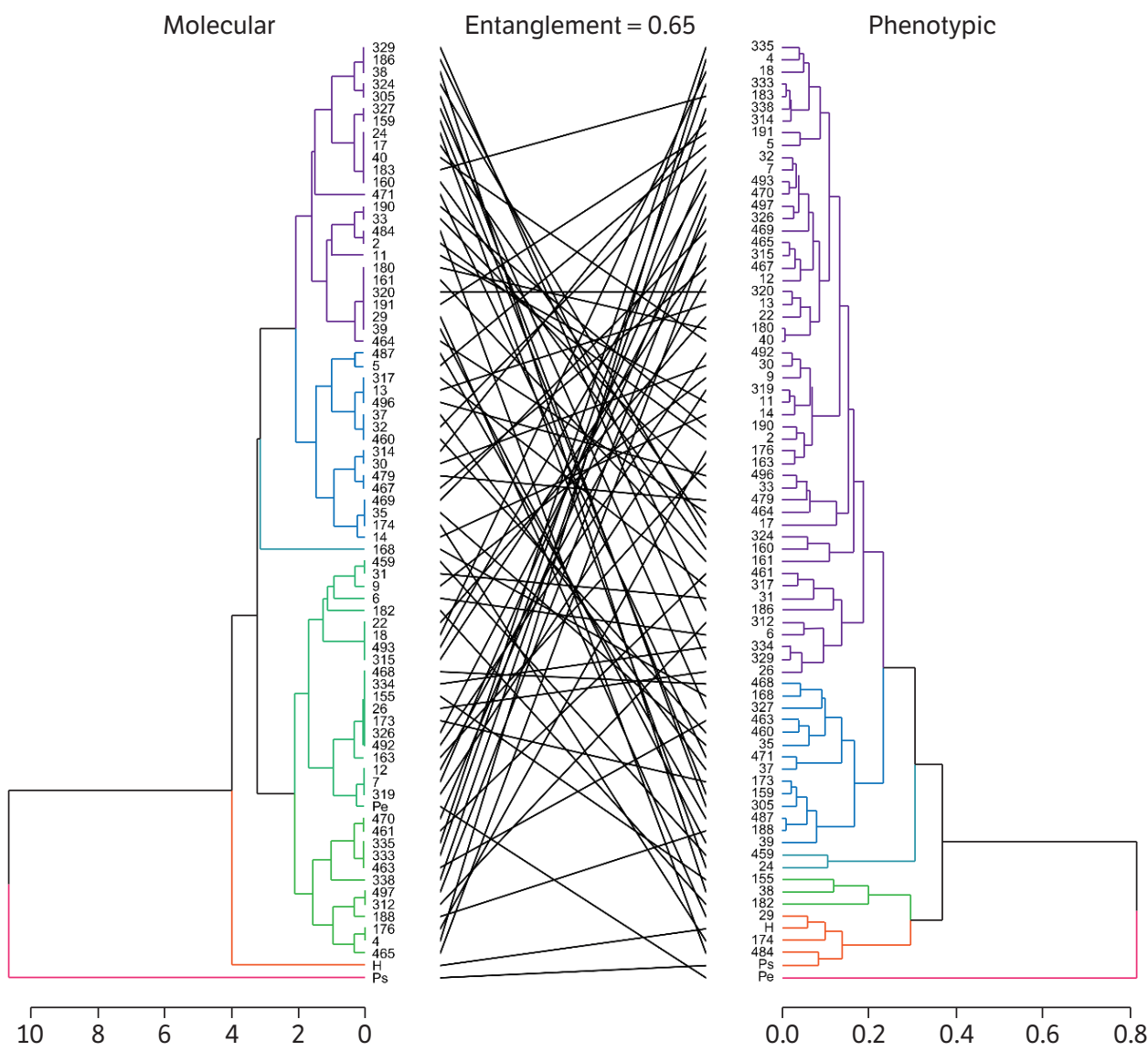

Figure 5. Entanglement among 77 genotypes, obtained by the Dendextend package, based on the Rogers and Euclidian distance, considering the agronomic and molecular information, respectively. 
of 0.65 was obtained, evidencing divergence in the distribution of accessions in both dendrograms. In general, the arrangement of genotypes was distinct for the two dendrograms. Moreira et al. (2018) evaluated entanglement among 65 accessions of Capsicum chinense through molecular and agronomic data and also observed divergence in the distribution of accessions in the dendrograms. A possible explanation for this distinct genotype arrangement in the dendrogram is the fact that the molecular markers used were not specific for certain phenotypic traits. They amplify more-conserved regions of the genomes, without the possibility of assimilating a molecular mark to a given phenotypic trait.

The clusters indicated groups with potential for use in future stages of the breeding program. Genotypes from the first backcross generation; e.g., 484 and 312, which had good agronomic performance and resistance to the virus and which were allocated to different groups, can be intercrossed. A new trend may thus arise in the breeding programs, such as recurrent selection in the $\mathrm{BC} 1$ generation with a view to accumulation of alleles linked to resistance to CABMV. These genotypes are also indicated as parents for the next backcross generation of the passion fruit breeding program aimed at resistance to CABMV.

\section{CONCLUSION}

The variability present in the $\mathrm{BC}_{1}$ population observed through agronomic, resistance, and molecular information allows for genetic gains to be obtained with the selection of resistant and agronomically superior genotypes.

The joint analysis of morphoagronomic and molecular information revealed divergence in the distribution of genotypes into the different clusters.

The genotypes 319, 7 and 12 closest to the recurrent parent were low performance for the agronomic traits and moderate resistance to CABMV, therefore they were not indicated for the generation advance.

Due to their good agronomic performance, resistance to the fruit woodiness virus, and genotypic and phenotypic distinction, genotypes 484 and 312 are recommended to compose the future stages of the passion fruit breeding program aimed at resistance to CABMV.

\section{FUNDING}

Fundação de Amparo à Pesquisa do Estado do Rio de Janeiro

[https://doi.org/10.13039/501100004586]

Coordenação de Aperfeiçoamento de Pessoal de Nível Superior

[https://doi.org/10.13039/501100002322]

Conselho Nacional de Desenvolvimento Científico e Tecnológico

[https://doi.org/10.13039/501100003593]

\section{AUTHORS' CONTRIBUTION}

Conceptualization, Preisigke S. C. and Viana A. P.; Writing - Original Draft, Preisigke S. C., Viana A. P. and Santos P. R.; Writing - Review and Editing, Preisigke S. C. and Santos E. A.; Data acquisition, Preisigke S. C., Santos V. O., Walter F. H. B., Silva F. A. and Ambrósio M.; Resources, Viana A. P.; Supervision: Preisigke S. C. and Viana A. P. 


\section{REFERENCES}

Allard, R. W. (1971). Princípios do Melhoramento Genético de Plantas. 2. ed. São Paulo: Edgar Blucher.

Assmann, A. P., Citadin, I., Santos, I. and Wagner Júnior, A. (2010). Reação de genótipos de pessegueiro à ferrugem-da-folha. Pesquisa Agropecuária Brasileira 45, 1, 32-40. https://doi.org/10.1590/S0100-204X2010000100005

Benchimol, L. L., Souza, C. L. and Souza, A. P. (2005). Microsatellite assisted backcross selection in maize. Genetics and Molecular Biology, 28, 4, 789-797. https://doi.org/10.1590/S1415-47572005000500022

Carvalho, B. M., Viana, A. P., Santos, P. H. D., Generoso, A. L., Corrêa, C. C. G., Silveira, V., Eiras, M. and Santos, E. A. (2019). Proteome of resistant and susceptible Passiflora species in the interaction with cowpea aphid-borne mosaic virus reveals distinct responses to pathogenesis. Euphytica, 215, 1-17. https://doi.org/10.1007/s10681-019-2491-5

Cazé, A. L. R., Kriedt, R. A., Beheregaray, L. B., Bonatto S. L. and Freitas, L. B. (2012). Isolation and characterization of microsatellite markers for Passiflora contracta. International Journal of Molecular Sciences, 13, 9, 11343-11348. https://doi.org/10.3390/ijms130911343

Cerqueira-Silva, C. B. M., Jesus, O. N., Oliveira, E. J., Santos, E. S. L. and Souza, A. P. (2015). Characterization and selection of passion fruit (yellow and purple) accessions based on molecular markers and disease reactions for use in breeding programs. Euphytica, 202, 345-359. https://doi.org/10.1007/s10681-014-1235-9

Cerqueira-Silva, C. B. M., Santos, E. S. L., Jesus, O. N., Vieira, J. G. P., Mori, G. M., Corrêa, R. X. and Souza, A. P. (2014 a). Molecular genetic variability of commercial and wild accessions of passion fruit (Passiflora spp.) targeting ex situ conservation and breeding. International Journal of Molecular Sciences, 15, 12, 22933-22959. https://doi.org/10.3390/ijms151222933

Cerqueira-Silva, C. B. M., Santos, E. S. L., Vieira, J. G. P., Mori, G. M., Jesus, O. N., Corrêa, R. X. and Souza, A. P. (2014 b). New microsatellite markers for wild and commercial species of Passiflora (Passifloraceae) and cross-amplification. Applications in Plant Sciences, 2, 2, 1-5. https://doi.org/10.3732/apps.1300061

Di Piero, R. M., Rezende, J. A. M., Yuki, V. A., Pascholati, S. F. and Delfino M. A. (2006). Transmissão do Passion fruit woodiness virus por Aphis gossypii (Glover) (Hemiptera: Aphididae) e colonização de maracujazeiro pelo vetor. Neotropical Entomology, 35, 1, 139-140. https://doi.org/10.1590/S1519-566X2006000100019

Doyle, J. J. and Doyle, J. L. (1990). Isolation of plant DNA from fresh tissue. Focus 12, 1, 13-15.

Fonseca, K. G., Faleiro, F. G., Peixoto, J. R., Junqueira, N. T. V., Silva, M. S., Bellon, G., Junqueira, K. P. and Vaz, C. F. (2009). Análise da recuperação do genitor recorrente em maracujazeiro-azedo por meio de marcadores RAPD. Revista Brasileira de Fruticultura, 31, 145153. https://doi.org/10.1590/S0100-29452009000100021

Freitas, J. C. O., Viana, A. P., Santos, E. A., Paiva, C. L., Silva, F. H. L. and Souza, M. M. (2016). Sour passion fruit breeding: Strategy applied to individual selection in segregating population of Passiflora resistant to Cowpea aphid-born mosaic virus (CABMV). Scientia Horticulturae, 211, 241-247. https://doi.org/10.1016/j.scienta.2016.09.002

Freitas, J. C. O., Viana, A. P., Santos, E. A., Silva, F. H. L., Paiva, C. L., Rodrigues, R., Souza, M. M. and Eiras, M. (2015). Genetic basis of the resistance of a passion fruit segregant population to Cowpea aphid-borne mosaic virus (CABMV). Tropical Plant Pathology, 40, 291-297. https://doi.org/10.1007/s40858-015-0048-2

[IBGE] Instituto Brasileiro de Estatística e Geografia (2019). Área destinada à colheita, área colhida, quantidade produzida e valor da produção da lavoura permanente. [Cited at Nov. 20, 2019]. Available at: https://sidra.ibge.gov.br/Tabela/1613

Marić, S., Bolarić, S., Martinčić, J., Pejić, I. and Kozumplik, V. (2004). Genetic diversity of hexaploid wheat cultivars estimated by RAPD markers, morphological traits and coefficients of parentage. Plant Breeding, 123, 366-369. https://doi.org/10.1111/j.1439-0523.2004.00956.x 
Meletti, L. M. M. (2011). Avanços na cultura do maracujá no Brasil. Revista Brasileira de Fruticultura, 33, 83-91. https://doi.org/10.1590/ S0100-29452011000500012

Moreira, A. F. P., Ruas, P. M., Ruas, C. F., Baba, V. Y., Giordani, W., Arruda, I. M., Rodrigues, R. and Gonçalves, L. S. A. (2018). Genetic diversity, population structure and genetic parameters of fruit traits in Capsicum chinense. Scientia Horticulturae, 236, 1-9. https://doi. org/10.1016/j.scienta.2018.03.012

Novaes, Q. S. and Rezende, J. A. M. (1999). Possível aplicação do DAS-ELISA indireto na seleção de maracujazeiro tolerante ao 'Passion fruit Woodiness Virus'. Fitopatologia Brasileira, 24, 76-79.

Oliveira, E. J., Soares, T. L., Barbosa, C. J., Santos-Filho, H. P. and Jesus, O. N. (2013 a). Severidade de doenças em maracujazeiro para identificação de fontes de resistência em condições de campo. Revista Brasileira de Fruticultura, 35, 485-492. https://doi.org/10.1590/ S0100-29452013000200018

Oliveira, E. J., Vieira, M. L. C., Garcia, A. A. F., Munhoz, C. F., Margarido, G. R., Consoli, L., Matta, F. P., Moraes, M. C., Zucchi, M. I. and Fungaro, M. H. P. (2008). An integrated molecular map of yellow passion fruit based on simultaneous maximum-likelihood estimation of linkage and linkage phases. Journal of the American Society for Horticultural Science, 133, 35-41. https://doi.org/10.21273/JASHS.133.1.35

Oliveira, G. A. F., Pádua, J. G., Costa, J. L., Jesus, O. N., Carvalho, F. M. and Oliveira, E. J. (2013 b). Cross-species amplification of microsatellite loci developed for Passiflora edulis Sims. in related Passiflora species. Brazilian Archives of Biology and Technology, 56, 785-792. https://doi.org/10.1590/S1516-89132013000500009

Pádua, J. G., Oliveira, E. J., Zucchi, M. I., Oliveira, G. C. X., Camargo, L. E. A. and Vieira, M. L. C. (2005). Isolation and characterization of microsatellite markers from the sweet passion fruit (Passiflora alata Curtis: Passifloraceae). Molecular Ecology Notes, 5, 863-865. https:// doi.org/10.1111/j.1471-8286.2005.01090.x

Paiva, C. L., Viana, A. P., Santos, E. A., Freitas, J. C. O., Silva, R. N. O. and Oliveira, E. J. (2014). Genetic variability assessment in the genus Passiflora by SSR markers. Chilean Journal of Agricultural Research, 74, 355-360. https://doi.org/10.4067/S0718-58392014000300015

Penha, H. A., Pereira, G. S., Zucchi, M. I., Diniz, A. L. and Vieira, M. L. C. (2013). Development of microsatellite markers in sweet passion fruit and identification of length and conformation polymorphisms within repeat sequences. Plant Breeding, 132, 731-735. https://doi. org/10.1111/pbr.12083

Pereira, G. S., Nunes, E. S., Laperuta, L. D. C., Braga, M. F., Penha, H. A., Diniz, A. L., Munhoz, C. F., Gazaffi, R., Garcia, A. A. F. and Vieira, M. L. C. (2013). Molecular polymorphism and linkage analysis in sweet passion fruit, an outcrossing species. Annals of Applied Biology, 162, 347-361. https://doi.org/10.1111/aab.12028

Ramos, H. C. C., Pereira, M. G., Gonçalves, L. S. A., Berilli, A. P. C. G., Pinto, F. O. and Ribeiro, E. H. (2012). Multivariate analysis to determine the genetic distance among backcross papaya (Carica papaya) progenies. Genetics and Molecular Research, 11, 1280-1295. https:// doi.org/10.4238/2012.May.14.2

Santos, A. A., Penha, H. A., Bellec, A., Munhoz, C. F., Pedrosa-Harand, A., Bergès, H. and Vieira, M. L. C. (2014). Begin at the beginning: A BAC-end view of the passion fruit (Passiflora) genome. BMC Genomics, 15, 816-832. https://doi.org/10.1186/1471-2164-15-816

Santos, E. A., Viana, A. P., Freitas, J. C. O., Rodrigues, D. L., Tavares, R. F., Paiva, C. L. and Souza, M. M. (2015 a). Genotype selection by REML/BLUP methodology in a segregating population from an interspecific Passiflora spp. crossing. Euphytica, 204, 1-11. https://doi. org/10.1007/s10681-015-1367-6

Santos, E. A., Viana, A. P., Freitas, J. C. O., Silva, F. H. L., Rodrigues, R. and Eiras, M. (2015 b). Resistance to Cowpea aphid-borne mosaic virus in species and hybrids of Passiflora: advances for the control of the passion fruit woodiness disease in Brazil. European Journal of Plant Pathology, 143, 85-98. https://doi.org/10.1007/s10658-015-0667-y 
Santos, E. A., Viana, A. P., Walter, F. H. B., Freitas, J. C. O., Ramos, H. C. C. and Boechat, M. S. B. (2019 a). First report of a genetic map and evidence of QTL for resistance to CABMV in a segregating population of Passiflora. European Journal of Plant Pathology, 155, 903915. https://doi.org/10.1007/s10658-019-01822-y

Santos, V. O., Viana, A. P., Preisigke, S. C. and Santos, E. A. (2019 b). Characterization of a segregating population of passion fruit with resistance to Cowpea aphidborne mosaic virus through morphoagronomic descriptors. Genetics and Molecular Research, $18,1-13$. https://doi.org/10.4238/gmr18255

R Core Team (2019). R: A language and environment for statistical computing. R Foundation for Statistical Computing, Vienna, Austria. [Cited at ago. 20, 2019]. Available at: http://www.R-project.org/

Silva, A. S., Oliveira, E. J., Haddad, F., Laranjeira, F. F., Jesus, O. N., Oliveira, S. A. S., Costa, M. A. P. C. and Freitas, J. P. X. (2013). Identification of passion fruit genotypes resistant to Fusarium oxysporum f. sp. passiflorae. Tropical Plant Pathology, 38, 236-242. https://doi.org/10.1590/ S1982-56762013005000008

Silva, F. H. L., Muñoz, P. R., Vincent, C. I. and Viana, A. P. (2015). Generating relevant information for breeding Passiflora edulis: genetic parameters and population structure. Euphytica, 208, 609-619. https://doi.org/10.1007/s10681-015-1616-8

Spooner, D., Treuren, R. and Vicente, M. C. (2005). Molecular markers for genebank management. IPGRI. Technical Bulletin n. 10. International Plant Genetic Resources Institute. Rome: International Plant Genetic Resources Institute.

Vanderplank, J. (2000). Passion flowers. Cambridge: The MIT Press.

Zerbini, F. M., Alfenas, P. F. and Andrade, E. C. (2005). O silenciamento de RNA como um mecanismo de defesa de plantas a vírus. Revisão Anual de Patologia de Plantas, 13,191-244. 